\title{
University of East Anglia
}

\author{
Andrew Cowan
}

Writing Worthless men: History and the literary

\begin{abstract}
:
My fifth novel Worthless men is based on numerous oral history recordings that I made in my mid-twenties, and is set on the home front during World War One. Nevertheless, if I had any ambitions in relation to history while writing the novel, these were only intermittently present to me, and if I was contributing to the historical turn in contemporary literature I was doing so more or less unknowingly. I might even have denied I was writing a historical novel. This essay represents a belated attempt to engage with a discourse of which I was largely unconscious at the time of writing the novel, and considers in particular the hazy issue of novelistic intention, the compositional challenges of incorporating research material into a fiction, the ethical question of the appropriation of traumatic experience, the difficulties in distinguishing fictional from historical discourse, the greater difficulty in distinguishing 'historical fiction' from other types of fiction, and concludes with a reconsideration of whether I have in fact written a historical novel.
\end{abstract}

\section{Biographical note:}

Andrew Cowan is a Professor of Creative Writing and Director of the Creative Writing programme at the University of East Anglia. His first novel, Pig (1994), won a number of literary awards, and was followed by Common ground (1996) and Crustaceans (2000), both of which received UK Arts Council bursaries, and What I know, which was the recipient of an Arts Council England Writers' Award and was published in 2005. His creative writing guidebook, The art of writing fiction, was published in 2011, and fifth novel, Worthless men, in 2013.

Keywords:

History - Historical fiction - Authorial intention - Composition Defamiliarisation 


\section{History and 'history'}

In 2013 I published a historical novel, Worthless men, which is set on the home front during the First World War. This was my fifth novel, and the first to look beyond my immediate experience and surroundings, or to feature a main protagonist who wasn't a more or less fictionalised version of myself. In fact Worthless men has five principal characters, two of them female, one of them dead. They are older and younger than I am, wealthier and poorer, and their view of the world is very different from mine, as is their world. And while my previous novels were all written in the first person or a limited, intimate third, my historical novel attempted to portray its characters in a rhetorically inflated third person of long multi-clause sentences that was intended (in so far as I can be sure of my intentions) to subordinate their individuality to an overarching narrative voice that was to be representative in some way of the impersonality of history, while also being capable of ironical self-awareness: that is, it was meant to represent both History and 'history'.

Worthless men derives in part from an archive of oral history recordings that I made in my mid-twenties, in addition to a great deal of supplementary research, and throughout the writing of the novel (it took five years, off and on) my most pressing concern was not so much to present a convincing account of the historical period in which it is set (though that too) but to achieve the narrative voice, construct the sentences, organise and incorporate the material. Technical or craft considerations were as important as historical ones. If I had any ambitions in relation to history, these were only intermittently present to me, only dimly apprehended, and if I was contributing to the historical turn in contemporary literature that is a counterpart to the narrative turn in contemporary historiography, I was doing so more or less unknowingly. I might even have denied I was writing a historical novel.

All of which is to say that this essay is itself an exercise in historical reconstruction, a retrospective attempt to engage with a discourse of which I was largely unconscious at the time of writing the novel. It is belatedly to approach an understanding of what might have been my motivations in entering what Maria Margaronis has called a 'noman's land on the borders of fact and fantasy' where the customary challenges of writing fiction are complicated by a 'minefield of hard questions'. These questions would include, in my case, 'What are the moral implications of taking someone else's experience, especially the experience of suffering and pain, and giving it the gloss of form?' and 'Can imaginative language discover truths about the past that are unavailable to more discursive writing?' (Margaronis 2008: 138). They might also include the questions of what, if anything, distinguishes historical from other forms of literary fiction, and whether the sense of otherness and absence that we experience in the face of the past is equally often a marker of our relationship with the present. 


\section{Some history}

In my guidebook, The art of writing fiction, I have described how I became, almost inadvertently, an oral historian:

Some time in the mid-80s, as I was chaining my bicycle to the railings outside Norwich City Hall, I got into a conversation with another cyclist, a trim, pugilistic-looking fellow who told me he'd recently completed a charity bike ride of almost 900 miles that had taken him less than four weeks. He was nearly eighty years old. His name was Snowy Fulcher, and he was, he said, a 'lifelong health and fitness fanatic'. He had trained as a junior boxer in the back room of a pub during the First World War, and the lessons had cost his father a shilling and sixpence. On Friday nights a ring would be roped off in the bar for competitive bouts against the boxers of other pubs, and Snowy had won back his father's investment, first time out. Later he'd learned gymnastics in a boys' club organised by the city's chief constable to keep hooligans like himself, he said, away from the pubs (Cowan 2011a: 101).

Snowy told me a lot more besides, not just that afternoon but over the following two years, during which time I visited him regularly to listen to his recollections of a city that persisted mainly in the memory of people like him. He described the cattle market in the centre of Norwich (then a car park, soon to become a shopping mall) and how he would earn pennies 'bullock whopping' - helping to herd the animals in from the countryside. He remembered the Corporation men sluicing manure down the hill at the end of the day, a slick of excrement that went straight into the river that ran alongside the most populous stretch of the city, a warren of alleys and yards, tiny dwellings and very large families. It was the details that most appealed to me, for instance the sight of his father, who had been conscripted, coming home on leave from the trenches, stinking, infested with lice, and covered in pus-filled boils.

But though I was a recent graduate of the MA in Creative Writing at the University of East Anglia (which is based in Norwich), my interest wasn't consciously novelistic. My year on the MA seemed only to have confirmed that I wasn't a writer. Unemployed, politically engaged, I was instead looking for work in community arts: I'd volunteered for a project in Corby, my home town, and was familiar with the practice of recording the testimony of 'ordinary' people for verbatim theatre productions. Nevertheless, verbatim theatre wasn't what I had in mind when I began approaching local charities for funding to buy the equipment that would enable me to record Snowy's memories. My intention was simply to preserve his memories for posterity, and I assumed the city would want to support me: with funding, with premises, perhaps with employment.

Snowy, like most of my interviewees, was glad of the opportunity to reminisce, and indulgent of my zeal for creating the archive: he introduced me to others, who introduced me to others, and before long I was spending hours most days transcribing the interviews. Optimistically, I headed each transcript with the words 'Norwich Oral History Archive', but for a year and a half the archive had no home besides my 
bedroom, and no source of funding other than a few small grants for equipment and stationery. Eventually I found a sponsoring organisation - a community skills centre for the unemployed - that allowed me to establish the project under the terms of a government job creation scheme, and for a year I was employed part-time on a subsistence wage and had the use of an office in a semi-derelict outbuilding. But then it was announced that the job creation scheme was to be abolished. Disheartened, defeated, I deposited a copy of my archive - around 200 cassette tapes and their transcripts - with the city library, entrusted the originals to the skills centre, and moved away from Norwich.

When I returned with my family seven years later I discovered that Snowy, among others, had died. The semi-derelict outbuilding had been demolished, with my tapes and transcripts inside, and the city library had burned to the ground, my duplicates destroyed. Norwich Oral History Archive was history.

By that time I had published my first novel Pig (1994), and while something of the experience of making the recordings had found its way into that book (the narrator visits his grandfather in an old folks' home and listens to him reminisce) very little of the period detail came from my recordings. Nevertheless I must have been aware of their novelistic potential: besides the duplicates I'd made for the library, I had photocopied some of the transcripts for myself, on the assumption that I would not be returning to Norwich. In part this was sentimental. The spur to writing Pig was the death of my grandfather, with whom I'd been very close, and I'd become similarly attached to several of the elderly people I interviewed for the archive: they are named on the acknowledgements page of Worthless men, a paratextual device that may be one marker, at least, of my authenticity as a historical novelist (de Groot 2010: 6). However, in much the same way that I collected newspaper stories and other ephemera - found letters and photographs, advertising copy and holiday brochures - I must have recognised in these interviews the possibility that I might, after all, become a novelist; I must have been thinking already in terms of 'material'.

\section{The archive}

It was twelve years before I looked again at the photocopies, wondering if they might contain the germ of a novel. I had just published my third book Crustaceans (2000), an emotionally draining attempt to describe the loss of a child, and felt I needed to turn my imagination outwards. But while the archive confirmed that I had a great deal of what Hayden White might call 'the unprocessed historical record' (1973: 341, original emphasis), I was unable to locate within it any 'discernible form' (342) or decide what, in all that stuff, might be of significance. If, as Linda Hutcheon says, historiography is 'as structured, coherent, and teleological as any narrative fiction' (1995: 78), my transcripts only occasionally gestured in the direction of a coherent, structured narrative: I had plenty of backdrop, but no story. I had information about 
housing and hygiene, pubs and prices and shops, elections and entertainments, but no sense of how this might be organised as 'a whole set of events considered as a comprehensible process with a discernible beginning, middle, and end' (White 1973: 343). Deterred by the recalcitrance of the material, and the evident limitations of my imagination, I turned back to what I knew, and wrote a novel called What I know (2005).

Five years later I returned to the archive with an inkling at last of how the material might be 'processed'. If I remained uncertain of my story, I had stumbled on my subject, the theme that would help me decide what to discount, what to retain, and how to incorporate it into a meaningful narrative. Serendipitously, I'd become aware of Ronald Aylmer Fisher, 'the father of modern statistics', and while I had little interest in statistical science, and even less ability to comprehend it, I was struck by the dedication of this idealistic and fiercely rational man to the advancement of mankind through the principles of genetic selection. Fisher was a 'eugenist' (Fisher 1914), a leading figure in what was - to my surprise - an intellectually respectable current of thought in the early years of the twentieth century (other prominent supporters included HG Wells, George Bernard Shaw and John Maynard Keynes).

The peculiarities of eugenical belief snagged my attention: for instance the claim that moral fibre, aesthetic appreciation, religious feeling, and virtues such as pity and patriotism were as favoured by evolution as physical fitness (Box 1978: 30); the possibly contradictory claim that poverty, promiscuity, criminality and other undesirable 'traits' were also inherited (Searle 1976: 31); and the debate over whether the war might be dysgenic in eliminating the best of men - those possessing the 'precious gifts, of health, courage and patriotism' (Box 1978: 54) - or else positively eugenic in effecting a necessary cull of the morally and physically unfit (Stepan 1987: 136).

Since my archive covered a period that coincided with the ascendency of such ideas, and tended to describe lives at 'the wrong end of the scale' (Box 1978: 26), in which poverty was endemic, families of a dozen or more commonplace, infant mortality high, and the burden on women especially harsh, this intellectual backdrop (invisible to my interviewees) appeared to offer a means of incorporating at least some of the material. That the case for eugenics was so often framed in agricultural terms (Darwin 1932: 1) gave unexpected resonance to Snowy's and others' recollections of the cattle market, and provided the temporal frame for my novel, which would take place over a single market day. But key to unlocking the archive was the realisation that I might incorporate the figure of RA Fisher by marrying his beliefs and irascible personality 'he knew and trusted the intuitions of thought ... he did not recognise or trust the infections of feeling' (Box 1978: 12) - to the more benign figure of a pharmacist whose premises overlooked Norwich cattle market. Mentioned in passing and with affection by several of my interviewees, this pharmacist was a friend to the women of the overcrowded slum housing alongside the river: mothers would go to him for 
'help' with unwanted pregnancies. In my novel (which is set in an unnamed town with an invented geography) he becomes the far less sympathetic Claude Dobson, whose dispensing of proprietory pills to 'maintain monthly regularity' (abortifacients) is motivated by a eugenical desire to control the numbers of the poor.

In his analysis of the work of the historian, and the extent to which it relies on procedures more commonly associated with the work of the novelist, Hayden White remarks:

It is sometimes said that the aim of the historian is to explain the past by 'finding', 'identifying', or 'uncovering' the 'stories' that lie buried in chronicles; and that the difference between 'history' and 'fiction' resides in the fact that the historian 'finds' his stories, whereas the fiction writer 'invents' his. This conception of the historian's task, however, obscures the extent to which 'invention' also plays a part in the historian's operations (1973: 342).

To which one might add that such a conception of the fiction writer's task also obscures the extent to which 'finding' plays a part in the fiction writer's operations. That I was able to invent a narrative using material from my archive is due to a series of 'finds' extraneous to the archive that begins with my stumbling upon an educational documentary about RA Fisher. But while this discovery of a theme allowed me to eliminate a great deal of material from consideration, it also introduced me to what White elsewhere calls "the problem" of the too much and not enough" (2005: 150). I had belatedly arrived at a solution to the problem of the 'too much', but I had also acquired a surer sense of the 'not enough'. My novel, it seemed, could only emerge through the accumulation of yet more material (additional research into eugenics and the war, for instance), which resulted in yet more productive discoveries. Principal among these was the concept of the 'worthless men' (Oram 1998): private soldiers from the social 'residuum' considered by their commanding officers to be lacking in the precious gifts of health, courage and patriotism. Crucial too was observation in Geoff Dyer's The missing of the Somme (1994) that 'the young men queuing up to enlist in 1914 have the look of ghosts. They are queuing up to be slaughtered: they are already dead' (1994: 6). This gave me my central character, Walter Barley, who stalks the streets of the novel without realising he is a ghost, a 'worthless man' who died in the Somme.

\section{The voice of the past}

That it took me so long to publish this novel (twenty-seven years after I first interviewed Snowy) is the outcome of several factors, including my initial reluctance to think of myself as a writer, and continuing with my sense of unreadiness in relation to the material. Other subjects pressed in on me with greater urgency, and resulted in other novels. But my delay, I suspect, was also on some level deliberate, an unconscious attempt to render the material doubly historical: not just about a past that 
I had not lived through, but sufficiently far in my own past that it might cease to seem my own.

Paradoxically, the fact that the archive was created by me and was in my sole possession appeared to weaken rather than strengthen my claim on it. Had the complete archive survived the library fire and the skills centre demolition, then it might have fulfilled the purpose for which my 'respondents' had agreed to be interviewed for it. They had offered their memories to posterity, understood as a public resource, an archive to which anyone might have access for whatever purpose. That 'anyone' might have included me, of course, and the 'purpose' might have included research for a novel. But the surviving archive - my fragment - was not a public resource, and my proprietorial claim on the material served only to amplify rather than mitigate my sense of unease, which finds its explanation both in Maria Margaronis's question about 'the moral implications of taking someone else's experience' (2008: 138) and in my relationship with the idealism of my younger, historical self.

In Literature and the human, Andy Mousley notes that there are 'conspicuously different ways of doing history' and suggests that the various historicisms might 'themselves be historicised so as to be understood as particular, historically specific approaches to the study of history' (2013: 42). Certainly my own brief career as an oral historian is to be explained less by an abiding interest in historical enquiry than by my coming into political awareness in the 1970s and 80s and my consequent commitment to the ideals of the community arts movement, then at its zenith in the United Kingdom. I aligned myself with a trend in the culture that was determinedly oppositional, premised on a view of the arts as elitist and obscurantist. Oral history was a part of this, dedicated to giving expression to the overlooked, the marginalised or excluded, and its textbook was Paul Thompson's The voice of the past, which identifies the 'social and political importance' of oral history as residing in the challenge it offers 'to the accepted myths of history, to the authoritarian judgement inherent in its tradition' (1978: 18). 'Oral history,' writes Thompson, 'gives history back to the people in their own words. And in giving a past, it also helps them towards a future of their own making' (226).

Unschooled in historical method, and unaware of any debates then current in the discipline, I readily subscribed to Thompson's view of a singular, conventional history that represented the past from the sole perspective of privilege and power. The aim was to give voice to 'the people', my people. But in attempting, years later, to make novelistic use of some of the transcripts this ease of identification was troubled by an awareness that these voices were only being given expression through a painstaking process of adaptation or incorporation, and in this regard, whether or not I was fully conscious of it, the voice of the past that spoke to me most insistently (and accusingly) was my own. 
Arguably the issue of appropriation - of 'taking someone else's experience' - is one that may also arise in novels of contemporary events, or in any strongly autobiographical novel. Arguably, too, the historical novelist is not taking anyone's actual experience but responding imaginatively to a previous textualisation of that experience, a prior narrative that describes or mediates it. And certainly, throughout the writing of Worthless men, I was conscious of the unreliability of memory - its tendency to embellish, rearrange or misremember - and circumspect in approaching the most anecdotal or previously narrativised of the material in the archive. Nevertheless, a voice of self-accusation continues to trouble me, and my best defence, I suspect, is not to be found in my primary role in establishing the archive, or in the time that has elapsed since I made the recordings, or in a textualist evasion of my responsibilities to my interviewees, or the impossibility now of seeking permissions, or in the hypothetical case of the public archive having survived, or in the extent to which I supplemented the transcripts with additional research. My justification is to be found in the degree to which I have managed to elaborate sympathetically upon the interviews through my imagination and the deployment of the 'literary, poetic and rhetorical devices' that Hayden White sees as crucial to distinguishing fictional from historical discourse (2005: 149): long multi-clause sentences, for instance, or the book-length trope of cattle being led to the slaughter, or the invention of a ghost as a principal character. Which suggests another paradox: that the more one 'processes' the historical record, the less one may be appropriating it.

\section{The 'historical novel'}

'The conjuring up of the past requires art as well as information,' writes White, for whom the significance of Primo Levi's If this is a man (1959) lies less in the truth of the 'information' it conveys than in the 'artistry' of its presentation (2005: 149). Through the devices of 'topoi, tropes and figures, schemata of thought, characterisation, personification, emplotment, and so on', Levi's account is elevated above testimony or history - the 'merely truthful' - to something as immersive and affecting as lived experience, thus transcending the 'truth-reality distinction' (149). Yet much as I find this argument persuasive, it serves only to distinguish the work of the novelist from that of the (presumably pre-postmodern) historian. Whether a similar distinction may be made between the historical novel and other types of novel is less certain since the conjuring up of the present requires just as much art - and possibly just as much information - as the conjuring up of the past. Artistry is equally as necessary to a novel about contemporary society as it is to a novel about the Holocaust, the First World War, or the court of Henry VIII. And if both history and the historical novel 'are discourses which construct rather than reflect, invent rather than discover, the past' (Currie 1998: 88) - which I don't doubt - it is equally true to say that the novel of contemporary society constructs rather than reflects, invents rather than discovers, the present. 
In writing Worthless men I certainly understood myself to be writing a novel set in the past, and by that token a 'historical' novel, but I had little sense of engaging with a distinct genre, the 'historical novel'. In Jerome de Groot's introductory guide, historical writing is identified 'within numerous fictional locales: romance, detective, thriller, counterfactual, horror, literary, gothic, post-modern, epic, fantasy, history, western, children's books' (2010: 2), an array of 'locales' so extensive it appears to deny any possibility of generic specificity. The historical novel emerges instead as a tendency or orientation available to almost all other genres. 'Indeed,' de Groot continues, 'the intergeneric hybridity and flexibility of historical fiction have long been one of its defining characteristics' (2), which may be as much as to concede that it is so mutable as to have no defining characteristics other than an interest in history, whether as subject or setting. For myself, in so far as I had any awareness of the 'historical novel', I took it to mean one of two things: those novels of the nineteenth century discussed in Georg Lukács's The historical novel (1962), which I had studied as an undergraduate, and the popular romance novels of costumery and swashbuckling that Perry Anderson describes as 'decadent representations of a remote past with no living connection to contemporary existence, but functioning rather as a rejection and escape from them' (Anderson 2011). I was attracted to neither possibility.

My acquaintance with Lukács would have been recent history to the young man conducting oral history interviews in the mid-eighties, but had become ancient history to the novelist writing Worthless men. My recollection was of a somewhat forbidding range of exemplars (books I had never been able to finish) and an equally forbidding set of precepts: for instance, that characters should be the unexceptional representatives of their age, both the product of the historical forces acting upon them, and participants in the progress of those forces; that this presentation of character and circumstance should be educative to readers, who might thereby be encouraged to see themselves as historical subjects and similarly contribute to the forward march of mankind; that the unobtrusive techniques of literary realism were the most effective vehicle for this, and that the works of Sir Walter Scott, especially Waverley (1814), offered the model to emulate.

Whether Lukács was as admonitory or prescriptive as I recalled, my understanding of the exploratory, contingent, unpredictable process of writing, and of its inability to predict the terms of 'its participation in the discourse that will condition its reception' (Cowan 2011b), meant that I would never consciously be inclined to adopt a polemical or pedagogical intention in the writing of Worthless men - or at least, not in the sense of offering my novel as an instrument in the cause of human progress. Nor did my sensibility (or sense of my abilities) incline me to write in the manner of the 'historiographic metafictions' that have come to constitute the canon of postmodern historical fiction: The French lieutenant's woman (1969), One hundred years of solitude (1970), Ragtime (1975), Midnight's children (1981), Waterland (1983). I had 
read and deeply valued each of these, without fully comprehending that they too were 'historical novels', performing in their self-awareness and formal inventiveness a breach with the naturalising tendencies of realist historiography, an insistence on the artifice of historical discourse that was itself at odds with Lukács's canonical writ.

Yet despite my reluctance to conceive of myself as a historical novelist, and of my novel as operating within a form that was primarily in 'dialogue with history rather than with the aesthetic strategies of fiction' (de Groot 2010: 48), Worthless men was undoubtedly informed by my response to RA Fisher and the 'eugenists' of the early twentieth century, resulting in a novel that sought both to remain in dialogue with the aesthetic strategies of fiction and to 'write back' to history. The attempt to offer a dramatised riposte to eugenical thought, for instance, is evidenced in the structural relationship of the two main characters: Walter Barley, recently killed in the trenches, and his commanding officer, the upper-class eugenicist Montague Beckwith, whose culpability in Walter's death reveals the extent of his own 'moral unfitness'. It is evidenced too in my effort to represent the war from the domestic and largely working-class perspective of the home front - an example, perhaps, of the 'democratic commitment to write previously unrepresented or under-represented individuals and groups of individuals into history' that Andy Mousley posits as one of several distinguishing features of the new historicism (2013: 43) and which may be seen to derive from the oral history movement.

If the emphasis here falls on the polemical intent of Worthless men, a more pedagogical aspect may be accessed through the question of whether 'imaginative language [can] discover truths about the past that are unavailable to more discursive writing?' (Margaronis 2008: 138), a question that gestures towards the 'deficit' model of historical writing 'in which the writer supplies the interiority or atmosphere deemed to be missing from history' (Nelson 2007). For Andy Mousley, such writing is expressive of literature's 'utopian value', in part because it shows 'what humans are capable of in terms of feeling and reflecting', in larger part because it represents an 'imaginative recreation of how individuals might have felt in the past, including how they felt they felt, and why they felt as they did' (2013: 46, original emphasis). Mousley traces this argument back to Aristotle via Sir Philip Sidney, who famously elevates poetry above the competing disciplines of philosophy and history on the basis of its supplying the 'true lively knowledge' missing from 'the dry-as-dust abstractions of philosophy, on the one hand, and the equally dry-as-dust, fact-based empiricism of history, on the other' (Mousley 2013: 41). Another word for such true lively knowledge (one much favoured by Mousley) is 'incarnation', which he further explains with reference to John Keats, for whom 'axioms in philosophy are not axioms until they are proved upon our pulses' (2010, citing a letter of 1818: 823). 
An important means to achieving such proof upon the pulse is through the 'deployment of resonating particulars' (Mousley 2010: 820, original emphasis). And indeed, however strongly (or weakly) my fiction may be motivated by a desire to engage with history, and however strongly (or weakly) that engagement is energised by contention, invariably it is an expression of my desire to engage with the materiality and mystery of the everyday, with the numinousness (or merely otherness) of the quotidian. This would explain not just my impulse to write a novel set in 1916, with the ambition of attempting to imagine that world in all its sensory and affective totality (however forlorn that ambition), but my inclination to write any novels at all. Always this is central to my interest: how to represent the textures of lived experience in order to create an 'immersive experience' (820) for the reader, which is coupled with an equally strong desire to represent the force and fluctuations of human emotions and bodily sensations. This humanist-realist impulse is no less genuine for being allied to an awareness that it can only ever be representation, 'a rhetorically produced effet de reel' (Vermeulen 2010: 483), and the impulse remains irrespective of the period in which the novel is set, reinforcing my sense of the indivisibility of the historical and the contemporary as subjects for fiction, and the difficulty of the distinction between the historical and the contemporary novel.

\section{'History is other'}

Besides my doomed archive of tapes and transcripts, there were three other 'outcomes' from my short career as an oral historian: a dozen filmed interviews that were deposited with the East Anglian Film Archive; a tape-slide package about the 'great flood' in Norwich of 1912 that was made for use by Social Services in 'reminiscence therapy'; and a book based on my interviews with Agnes Davey, a former cook to the Colman family (of mustard fame), whose reminiscences contained such a humorous, vivid and fluent account of her upbringing in one of the impoverished, overpopulated yards in the oldest quarter of Norwich that I was able to edit the transcripts in the form of her autobiography, which was eventually published by a local press as Hard up street (Davey 1997). In my short foreword to this book I invoked, inevitably, the famous first line of LP Hartley's novel The go-between (which is set near Norwich): 'The past is a foreign country: they do things differently there' (1971: 7).

This conception of the past as foreign, as other, provides one explanation for its allure, both for writers and readers of historical fiction, and prompts Jerome de Groot to propose at the beginning of The historical novel that 'History is other, and the present familiar' (2010: 3), which he subsequently reformulates as: 'History is other, and made familiar through the illusions of fiction' (94). Besides the highly questionable implication that the present cannot itself be 'other', the dubious corollary of these remarks is that historical fiction serves to make history more like the present: 
more immediate, more knowable, a lot less other. Debatable as this may be, the assertion that the 'illusions of fiction' help make the other familiar also proposes a reversal of what has become an axiom of Creative Writing pedagogy, that the purpose of literature is to defamiliarise, to 'make strange' the commonplace. This derives of course from Victor Shklovsky's seminal 1917 essay 'Art as technique', which attempts to define what makes literature 'literary':

Habitualization devours works, clothes, furniture, one's wife, and the fear of war ... And art exists that one may recover the sensation of life; it exists to make one feel things, to make the stone stony. The purpose of art is to impart the sensation of things as they are perceived and not as they are known. The technique of art is to make objects 'unfamiliar,' to make forms difficult, to increase the difficulty and length of perception because the process of perception is an aesthetic end in itself and must be prolonged (1965a: 12).

In other words, if historical fiction is to be considered literary, it too must resist the habitualised, the already known, and remain in dialogue with what de Groot terms 'the aesthetic strategies of fiction' and Shklovsky calls 'the technique of art'; it too must seek to impart the sensation of things through the defamliarising procedures of the literary.

My first acquaintance with Shklovsky and Russian Formalism occurred around the same time that I was reading Georg Lukács, and is the 'critical' encounter that has had the most enduring influence on my practice as a teacher of Creative Writing while continuing to offer the most satisfying justification for my practice as a novelist. My own 'art', I feel, derives from a compulsion to recover the sensation of life, and is frequently prompted by a sense of the particularity and peculiarity of the domestic and the everyday. The effort always is to find the language that will 'impart the sensation of things as they are perceived and not as they are known', an effort that repeatedly delivers me to another version of the problem of the 'too much and not enough': that there are always too many words, and too many familiar phrases, while seemingly never enough new words or better words. The fresh phrase is forever elusive; the language is lacking.

The technique of 'making strange' clearly cannot be understood as an operation that the writer performs on reality itself, however 'other' or 'familiar' it may be, and the reader's perceptions of that reality cannot be prolonged except through a medium of representation. The work of defamiliarisation must occur at the level of language and form, both in the composition and in the reception. In my own case this stops some way short of baring my devices in the manner of a Tristram Shandy (1759), so much admired by Shklovsky as 'the most typical novel in world literature' because the most formally challenging and unorthodox (1965b: 57). Worthless men doesn't explicitly advertise its fictionality; nor does it invest in 'difficulty' to anything like the degree advocated by Shklovsky. But neither is it straightforwardly realist or wholly lacking in 'self-conscious textualism' (Currie 1995: 14). Its claim to historical veracity is 
problematised by having as its central character a ghost, while it resists, albeit mildly, the naturalisation of language that creates the supposed 'transparency' of realism through, for instance, its use of prominent sub-headings, a somewhat elevated register, the conspicuously lengthy sentences, and the incorporation of rhythmical lists of ailments, shop names, pharmaceutical products, and so on.

Yet however much I might wish to insist that the challenge of defamiliarisation is not a function of the historical period in which a novel is set, and that the task of composition will be equally difficult regardless of whether the novel concerns the past or the present, and however much I might want to assert that the present, too, can be striking in its 'otherness', I do also recognise that a large part of the appeal of my oral history recordings lay in the beguiling strangeness of the world they described. The fact that the Norwich they conjured was frequently as familiar to me as it was unfamiliar produced a curious - indeed uncanny - doubling of perspective. The recollections of my interviewees opened up a palimpsestic perspective on neighbourhoods I thought I knew well, in which the present was made newly strange by the revelation of what it had replaced: materially, socially and culturally. And in this regard, the dense specificity of my interviewees' recollections made present an absence; in conjuring a lost world into imaginative being their memories made me aware of the loss of that world. My desire to make a novel out of the material in my archive was then less to do with my wanting to engage with the larger movements of history, or to participate in an already populous field of historiography, or even to respond to the rankling otherness of eugenical thought; it was primarily motivated by my desire to retrieve through evocative language (through the description of 'resonant particulars') both the feel of what was gone and, perhaps crucially, something of the feeling provoked by its passing. And this, I am sure, is consistent in everything I have written.

My understanding of my own fiction is that it is always a form of reparation, an attempt to reconcile myself to what is missing or lost. Besides commemorating my grandfather, my first novel Pig celebrates and mourns a doomed relationship and a post-industrial loss of community. Common ground (1995) concerns lost habitats, Crustaceans the death of a child, What I know failed ambition and missed opportunity. My present novel-in-progress concerns the irrecoverable intensities of childhood and the repudiation of Sixties optimism. But whatever the larger theme, and whatever the story, each of my novels is driven by a compulsion to recover the sensation of life, to make the stone stony, however much that compulsion is coloured by a melancholy intuition of the momentariness of perception and the impermanence even of stones. In the instant of perceiving, the stone is already passing into the past, along with the person who perceives it, and my sense of the poignancy of this moment, which I suspect lies at the heart of all my writing, is profoundly rooted in my own inability to fully inhabit the present or relinquish the past, while being endlessly productive of the desire to continue writing fiction, whether that fiction is set in the 
historical past or in a contemporary moment that forever anticipates its future recollection as the past.

\section{Works cited}

Anderson, P 2011 'From progress to catastrophe' London Review of Books 33:15 (July), at http://www.lrb.co.uk/v33/n15/perry-anderson/from-progress-to-catastrophe (accessed 29 June 14)

Box, JF 1978 RA Fisher: The life of a scientist, New York: John Wiley \& Sons

Cowan, A 2011a The art of writing fiction, Harlow: Pearson

Cowan, A 2011 b 'Blind spots: What creative writing doesn't know' TEXT 15:1 (April), at http://www.textjournal.com.au/april11/content.htm (accessed 8 September 2014)

Cowan, A 2013 Worthless men, London: Sceptre

Currie, M (ed) 1995 Metafiction Harlow: Longman

Currie, M 1998 Postmodern narrative theory, Basingstoke: Palgrave

Darwin, Leonard 1932 What is eugenics? New York: The Third International Congress of Eugenics

Davey, MA 1997 Hard up street: Growing up in King Street, Norwich, 1919-1947 Dereham: Larks Press

de Groot, J 2010 The historical novel, Abingdon: Routledge

Dyer, G 1994 The missing of the Somme, London: Hamish Hamilton

Fisher, RA 1914 'Some hopes of a eugenist' Eugenics Review 5, 309-15

Hartley, LP 1971 [1953] The go-between, Harmondsworth: Penguin

Hutcheon, L 1995 [1988] 'Historiographic metafiction', in M Currie (ed) Metafiction, Harlow:

Longman, 71-91

Lukács, G 1962 The historical novel, Harmondsworth: Penguin

Margaronis, M 2008 'The anxiety of authenticity: Writing historical fiction at the end of the twentieth century’ History Workshop Journal 65.1, 138-60

Mousley, A 2010 'The new literary humanism: Towards a critical vocabulary' Textual Practice 24:5, 819-39

Mousley, A 2013 Literature and the human: Criticism, theory, practice, Abingdon: Routledge

Nelson, C 2007 'Faking it: History and creative writing' TEXT 11:2 (October), at http://www.textjournal.com.au/oct07/nelson.htm (accessed 28 April 2014)

Oram, G 1998 Worthless men: Race, eugenics and the death penalty in the British army during the First World War, London: Francis Boutle

Searle, GR 1976 Eugenics and politics in Britain, 1900-1914, Leyden: Noordhoff International Publishing

Shklovsky, V 1965a [1917] 'Art as technique', in Russian formalist criticism: Four essays edited \& translated by LT Lemon and MJ Reis, Nebraska: University of Nebraska Press, 3-24

Shklovsky, V 1965b [1917] 'Sterne's Tristram Shandy:Stylistic commentary', in Russian formalist criticism: Four essays translated by LT Lemon and MJ Reis, Nebraska: University of Nebraska Press, 25-57

Stepan, N 1987 “"Nature's pruning hook”: War, race, and evolution, 1914-1918', in JWN Bean (ed) The political culture of modern Britain, London: Hamish Hamilton, 129-45 
Thompson, P 1978 The voice of the past: Oral history, Oxford: Oxford University Press

Vermeulen, P 2010 'Greenblatt's melancholy fetish: Literary criticism and the desire for loss' Textual Practice 24:3, 483-500

Wallace, D 2011 'Letters' London Review of Books 33:16 (August), at http://www.lrb.co.uk/v33/n15/perry-anderson/from-progress-to-catastrophe (accessed 29 June 14)

White, H 1973 'Introduction to metahistory', in D Walder (ed) Literature in the modern world, Oxford: Oxford University Press in association with the Open University, 341-6

White, H 2005 'Introduction: Historical fiction, fictional history, and historical reality' Rethinking History 9:2/3 (June/September), 147-57 